\title{
Prêmio 1994 em Homenagem a Fred L. Soper (1893-1976)* para Publicações no Campo da Saúde Interamericana
}

Este é o anúncio e solicitação de propostas para o prêmio de $1994 \mathrm{em}$ homenagem a Fred L. Soper, ex-Diretor da Organização Pan-Americana da Saúde (Escritório Regional da Organização Mundial da Saúde para as Américas) de 1947 a 1959.

Além de seus serviços na OPAS/OMS, o Dr. Soper desempenhou papel da maior relevância na luta contra a febre amarela e outras doenças infecciosas no Brasil como parte do seu trabalho com a Fundação Rockefeller nas décadas de 20 e 30 , no controle do tifo na África do Norte e na Itália durante a Segunda Gerra Mundial. Foi ele, realmente, uma das grandes personalidades do século na saúde interamericana.

Este Prêmio é outorgado anualmente ao autor ou autores de uma contribuição científica original que contenha informaçð̃es ou idéias novas no amplo campo da saúde pública, de especial relevância para a América Latina ou o Caribe, ou para ambos. O trabalho poderá consistir de relatório com base na análise de novos dados, obtidos através de estudos experimentais ou de observação, ou um novo enfoque à análise dos dados já existentes. Se dá preferência a estudos que incluam mais de uma disciplina e trabalhos relacionados com doenças infecciosas, que foram a preocupação do Dr. Soper, durante toda sua vida.

Somente os trabalhos publicados em jornais científicos latino-americanos incluídos no Index Medicus ou em publicaçōes oficiais da Organização Pan-Americana da Saúde serão tomados em consideração. Ademais, o Prêmio está restrito a contribuiçőes por autores que estejam vinculados a instituiçőes de docência, de pesquisa ou de serviço localizadas em países da América Latina e do Caribe (inclusive os Centros da Organização Pan-Americana da Saúde).

Os Fundos do Prêmio são administrados pela Fundação Pan-Americana de Saúde e Educação (PAHEF), que recebe contribuições voluntárias designadas para esse propósito e os mantêm em conta separada. O Prêmio consiste de um certificado apropriado e uma compensação monetária no valor de US\$ 400.00. O vencedor, ou vencedores, do Prêmio anual, será nomeado por um Comitê do Prêmio, composto de representantes designados pela OPAS e PAHEF, ficando a seleção final a cargo do Diretório da PAHEF.

Os trabalhos apresentados pelo autor, ou autores, ou em nome destes, poderão ser considerados para o Prêmio Fred L. Soper. Para o Prêmio de 1994, apenas os trabalhos publicados durante o ano calendário 1993 serão admitidos; os trabalhos submetidos à apreciação deverão ser recebidos até 31 de março de 1994, no seguinte endereço:

\author{
Secretário Executivo \\ PAHEF \\ 525 23rd Street N. W. \\ Washington, D. C. 20037, USA
}

Transcrito de documento enviado pela PAN AMERICAN HEALTH AND EDUCATION FOUNDATION (PAHEF), com a finalidade de obter ampla divulgação da matéria junto à comunidade científica. 